\title{
Decolonising Local Knowledge - Arhuaco Filmmaking as a Form of Cultural Opposition*
}

\section{Agata Lulkowska**}

Can filmmaking as a form of intercultural communication serve as an apparatus for self-identification and cultural opposition to established North/West knowledge production hubs? Based on extensive fieldwork in the Sierra Nevada and detailed analysis of the Arhucao films and their production and distribution strategies, this article explores the possibility of utilising film and audio-visual communication as a way to decolonise local knowledge. Following decades of persecutions, hostility, ill-treatment and cultural violence, the work of Zhigoneshi (and, later, Yosokwi) communication collectives not only helped to nourish the cultural identity of the indigenous communities of Sierra Nevada de Santa Marta, but it also turned them into proud ambassadors of indigenous values on the international level. Prolific in their internal and external communication practices, they regained agency as full participants of intercultural dialogue, which focuses on the importance of the inclusion, diversity and de-westernisation of local knowledge. While acknowledging its own limitations and the author's inevitable positionality, this article also reflects on further steps that the European and Western collaborators and institutions need to take to accomplish the vision of decolonisation. It concludes with acknowledging the work of the Arhuaco filmmakers and their allies in providing an invaluable contribution to strengthen this discussion and enable the shift towards a more all-embracing pattern of knowledge production and dissemination based on quality and importance and less so on stereotypical preconceptions and geographical location.

Keywords: filmmaking, decolonisation, intercultural communication, Arhuacos, self-preservation, local knowledge. doi 10.11144/javeriana.mavae16-2.dlka

Fecha de recepción: 21 de diciembre de 2020

Fecha de aceptación: 22 de marzo de 2021

Disponible en línea: 1 de julio de 2021

* Reflexive article based on a collaborative investigation with the Zhigoneshi collective back in 2015-2016.

** Senior Lecturer in Film Production at the Staffordshire University, interdisciplinary researcher, filmmaker, photographer, and editor at the at The International Journal of Creative Media Research, and the director of Communities and Communication — an international interdisciplinary conference and festival. Agata Lulkowska holds a practicebased (film) PhD from Birkbeck in Iberian and Latin-American Studies, University of London, MA in Film and Media Studies at Jagiellonian University, Cracow, Poland, unfinished MA in Film Direction at Silesian University, Katowice, Poland, and a First-Class Honours degree in Digital Media Arts at London South Bank University.

ORCID: 0000-0003-1685-1275

Correo electrónico: Agata.Lulkowska@staffs.ac.uk ID

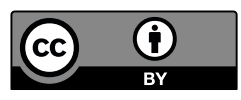




\section{Descolonización del conocimiento local: el cine arhuaco como forma de oposición cultural}

¿Puede el cine, como forma de comunicación intercultural, servir como un aparato para la autoidentificación y la oposición cultural a los centros de producción de conocimiento establecidos en el noroeste? A partir de un extenso trabajo de campo en Sierra Nevada y un análisis detallado de las películas arhuacas y de sus estrategias de producción y distribución, este artículo explora la posibilidad de utilizar el cine y la comunicación audiovisual como una forma de descolonizar el conocimiento local. Luego de décadas de persecuciones, hostilidad, malos tratos y violencia cultural, el trabajo de los colectivos de comunicación Zhigoneshi (y, más adelante, Yosokwi) no solo ayudó a nutrir la identidad cultural de las comunidades indígenas de la Sierra Nevada de Santa Marta, sino que también los convirtió en orgullosos embajadores de los valores indígenas a nivel internacional. Prolíficos en sus prácticas de comunicación interna y externa, recuperaron la agencia como participantes plenos del diálogo intercultural, que se centra en la importancia de la inclusión, diversidad y des-occidentalización del conocimiento local. Si bien reconoce sus propias limitaciones y la inevitable posicionalidad del autor, este artículo también reflexiona sobre los pasos adicionales que los colaboradores y las instituciones europeos y occidentales deben tomar para lograr la visión de la descolonización. Se concluye reconociendo el trabajo de los cineastas arhuacos y sus aliados al brindar una contribución invaluable para fortalecer esta discusión y permitir el cambio hacia un patrón más integral de producción y difusión del conocimiento basado en la calidad e importancia y menos en los preconceptos estereotípicos y la ubicación geográfica.

Palabras clave: cinematografía, descolonización, comunicación intercultural, arhuacos, autoconservación, conocimiento local.

\section{Descolonização do conhecimento local: o cinema arhuaco como forma de oposição cultural}

0 cinema, como forma de comunicação intercultural, pode servir de aparelho de autoidentificação e oposição cultural aos centros de produção de conhecimento estabelecidos no Noroeste? Com base em um extenso trabalho de campo na Sierra Nevada e uma análise detalhada dos filmes Arhuaco e de suas estratégias de produção e distribuição, este artigo explora a possibilidade de usar o cinema e a comunicação audiovisual como forma de descolonizar o conhecimento local. Após décadas de perseguição, hostilidade, maus-tratos e violência cultural, o trabalho dos coletivos de comunicação Zhigoneshi (e, mais tarde, Yosokwi) não só ajudou a nutrir a identidade cultural das comunidades indígenas da Sierra Nevada de Santa Marta, como também as fez orgulhosos embaixadores dos valores indígenas no nível internacional. Prolíficos em suas práticas de comunicação interna e externa, recuperaram a agência como participantes plenos do diálogo intercultural, que enfoca a importância da inclusão, diversidade e desocidentalização do conhecimento local. Embora reconheça suas próprias limitações e a inevitável posição do autor, este artigo também reflete sobre os passos adicionais que colaboradores e as instituições europeus e ocidentais devem dar para alcançar a visão da descolonização. Conclui-se reconhecendo o trabalho dos cineastas Arhuaco e seus aliados, fornecendo uma contribuição inestimável para fortalecer esta discussão e permitir a mudança em direção a um padrão mais abrangente de produção e disseminação de conhecimento baseado na qualidade e importância e menos em preconceitos estereotipados e a localização geográfica.

Palavras-chave: cinematografia, descolonização, comunicação intercultural, arhuacos, autopreservação, conhecimento local. 


\section{Conceptualising intercultural communication as a decolonial tool}

$>$ What is the principle behind the idea to decolonise local knowledge, and how might intercultural communication be seen as a possible way to achieve that? As the example of Zhigoneshi productions proves, a strong message communicated in the right contexts can become an embodiment of agency and intention to overcome the remains of colonial structures of oppression. This can be achieved by reversing the (so far failed) logic of who should represent whom, for what reason, and with what intention. The interculturality of communication which this article is concerned with focuses on what Bhambra (2014) describes as "imperial interlocutors (Europe and the West)" (115) and their response and attitudes towards indigenous communicators. Following decolonial logic, this article not only aims to challenge the existing historical narratives that favour the "imperial interlocutors" validity. More importantly, it hopes to prove that this process has already happened (regardless of whether or not all parties are fully aware of it), and the Arhuaco filmmaking from the Sierra Nevada de Santa Marta is a great example of that process. However, it is important to acknowledge this article's limitations and the author's inevitable positionality. By focusing on the international and intercultural dimension of this dialogue, a lot of important local work exploring Zhigoneshi practice did not make it into this article. Nevertheless, I would like to acknowledge the importance and huge role of various indigenous institutions and organisations in Colombia, as well as local academic circles. In both cases, the subject of Zhigonshi work has been explored in more details and with more far-reaching consequences. As a person heavily involved in the work on decolonising arts curriculum, I am also painfully aware of the challenges of the task and how incomplete this article might seem in that context. Nevertheless, bringing attention to the intercultural and international context of Zhigoneshi work serves its purpose. Furthermore, the transculturality of the communication processes we are concerned with here begs the question of the purpose of local knowledge production. Indigenous cultures with oral traditions do not need to reach for cameras for their own educational objectives. They do so for reasons which transcend beyond the internal needs of their communities. Quite in contrast to that, many Western filmmakers and academics who portray "remote" traditional groups do not seem to concern themselves with the response from these very communities. Often, they do not even bother to reach out. To borrow Bhambra's (2014) words, "History became the product of the West in its actions upon others" (116), which also encompasses the "domination the 'other"' (ibid.). Following Said, Bhambra suggests that decolonialism should take the form of a "crisis that fractures the complacent rendering of the 'other' as passive and docile and which challenges the assumptive conceptual framework underpinning such depictions" (ibid.). A more fundamental and profound transformation of these narratives must follow. It is also echoed by Spivak, who ponders about the voice of the subaltern in relation to Western discourse. 
Moreover, it is essential we start thinking about knowledge production from a global perspective instead of constantly favouring existing knowledge hubs that perpetuate their own self-importance. Effectively, this article seeks to contribute to the conversation of the importance of epistemic decolonisation. With this introduction, it hopefully becomes clear why McLuhan's prophecy makes so much sense in this context.

\section{Decades of persecution and cultural violence}

When Marshall McLuhan announced that medium is the message almost half a century ago (1964), the Arhuaco community from Sierra Nevada de Santa Marta in northern Colombia was facing a challenging period in their history. The Capuchins who arrived at the Sierra in 1916 were continuously attempting to erase the local culture by forbidding the use of the Arhuaco language and other forms of cultural identity. Some of these painful moments got documented by Swiss ethnographer, Gustaf Bolinder, who predicted a sad end to the Arhuaco culture at that point (Muñoz 2017).

Strangely enough, McLuhan's publication date also coincides with the release date of "El Valle de los Arhuacos" (The Valley of the Arhuacos), a film by Vidal Antonio Rozo. The film viciously portrays the community as the incarnation of the worse possible qualities, suggesting their doomed future. A few years before, in 1952, a missionary, Padre Jose de Vinalesa, wrote a book about the Arhuacos. His description was not very favourable for the community, which he describes as sombre and immersed in the fantasy of enslaving religious system. He adds an insult after an insult: "El indio Arhuaco arrastra consigo los defectos que son comunes a casi todos los indios; los cuales, generalmente, son egoístas, recelosos, sin aspiraciones; inclinados a la holganza y a la embriaguez."1 (de Vinalesa, 1952, 31). He ridicules the community's spiritual leaders and mocks the use of the sacred coca plant:

El abuso de la cocaína produce en los arhuacos una serie de raros fenómenos tanto fisiológicos como de orden moral [...] Los hace aparecer tímidos o cobardes; los vuelve taciturnos y misteriosos; manteniéndolos casi de continuo como semi - letargados. (de Vinalesa 1952,42$)^{2}$

As if that was not enough, he concludes that the Arhuacos have a contract with the Devil (de Vinalesa 1952, 51).

If we compare that with some first-hand confessions, it adds cruelty to this already very disturbing image. Vicencio Torres Marquez, the author of the "Los indígenas arhuacos" and "La vida de la civilización" (1978) was an orphan from an early age and he was taken to the Capuchins orphanage in Nabusímake. In one of the passages of his testimonies, he states: "Nos cambiaron el modo de vestir contra del deseo de los jefes indígenas que era que nos dejaran con nuestro cabello largo y el mismo vestido propio" (Torres Marquez 1978, 8). ${ }^{3}$ Further, he states: "Los misioneros siempre se opusieron a que siguiéramos nuestras costumbres propias y lo que querían era que siguiéramos la vida de la civilización"4 (Torres Marquez 1978, 9). 
Decades later, things seem to look much better. A few more balanced films were made in the region, most notably, Robert Gardner's "Ika Hands" (1988), and two films by Alan Ereira: "From the Heart of the World" (1990), and "Aluna" (2012). Any detailed analyses are beyond the scope of this article; it is enough to say that, especially in the two latter cases, the films did not help the community despite the filmmaker's apparently best intentions. The British director presented himself as the only link between the West and the "remote" community, "rediscovering" their secret traditions and allowing the viewers to rely on his "exclusive access" to the community. It is important to mention here that both "From the Heart of the World" and "Aluna" focus specifically on the Kogui community - one of the three indigenous nations inhabiting the Sierra (next to Arhuacos, Wiwa and the Kankuamos, the last community remaining the weakest link to their traditional lifestyles as the result of decades of persecutions and deculturalization). Afterwards, Ereira (1992) described his experiences in the book which took its title from the film, "The Heart of the World." The book was republished two years later under a new title, "The Elder Brothers," and again in 2009 as "The Elder Brother's Warning."

Having read the original edition of Ereira's book before my first visit to the Sierra, I seriously questioned my entire research project. He warns us: "[The Kogui] want only silence. They need very little from us, except to be left in peace" (Ereira 1992 226). My upcoming research project in the Sierra suddenly felt like a grave sacrilege with a potential to break some unwritten rules and cross the line that should never be crossed. To my surprise, the Kogui (as well as the Arhuacos and Wiwas) I met during my initial fieldwork (September-October 2012) turned out to be not only friendly and open, and altogether far away from the violent society of misanthropes pictured in Ereira's warning. The more I explored the communities of the Sierra, the more suspicious I became of the way they were portrayed by "the BBC," as the Kogui called Ereira during their collaboration.

Years later (2015-2016), during my collaboration with Amado Villafaña and his filmmaking crew, it quickly became clear that the communities not only actively look for external allies, but they also oppose the idea of being "talked about" without a proper collaborative approach.

How does a seemingly positive film made with respect to the community produce the opposite result? The fundamental problem with these films lies, precisely, in the assumption that the communities need someone external who should "speak for them." By presenting himself as the only person with access to the communities, Ereira inevitably deprives the Arhuacos and Kogi of their possibility to speak for themselves. A very skilful and accomplished filmmaker, he makes an effective use of this intercultural encounter. Sadly, it only reinforces the (stereotypical) division between the civilised and the "savage."

Represented by a reputable institution with outstanding traditions, the attention for his films is automatically guaranteed. Would the same be the case if the Arhuacos came to the UK to make a film about the BBC (a project I would be very tempted to organise)?

Villafaña's dissatisfaction about both BBC productions was based on the fact that by then the collectives were capable of having contributed to the production on more equal rights. As a community that is alive and proactive in their self-representation practices, they find it arrogant and paternalistic if the task is done for them.

To my surprise, Villafaña and his team used recorded meetings with the British director in one of their own films to prove the director's seemingly stubborn unwillingness to understand the community's request for equal contributions in the filmmaking process. This revealed some significant differences between these two points of view. We should once again ask the questions of who has the right to represent whom, for what reason, using what kind of language, and in which contexts? 


\section{Communication as a tool for social change}

Elsewhere, I write about the origins of Zhigoneshi filmmaking and their trajectory from victims of violence to emancipated communicators and activists (Lulkowska 2018, 2020). Here I just want to remind that the direct incentive for the adoption of cameras in the region was brutal, inescapable violence in the region, and threat of displacement which affected Villafaña, forcing him to react. He has learnt the language of filmmaking and reached for cameras to make his external allies aware of the violence affecting his people. Years later, his films also started to address questions of misrepresentations and cultural violence. To remind the conceptual context for this debate, it is handy to borrow Freya Schiwy's words, where she suggests that the subaltern status of indigenous techniques of representation, as a reaction to the "hegemonic structure of thinking" resulted from colonialist geopolitics which implies that the North (West) produces theoretical knowledge while the Third and Fourth worlds only produce culture, or in best cases, "local knowledge" (Schiwy 2009, 3). The case of the Arhuacos was a perfect attempt to contest this situation. Schiwy further argues that, when indigenous communities use audio-visual medium, they are commonly considered "oral cultures using Western technology." This insinuates constant appropriations, implying that "having emerged in capitalist, colonial and patriarchal contexts, audio-visual media carry the burden of a colonial geopolitics of knowledge" (ibid.). However, the situation in some Latin-American counties, Canada, the United States, and Australia suggests some optimism that is based on two observations: "First, that video allows decentralised communication and representation; second, that the medium enables liberation from the requirements of literacy and state education" (ibid.).

After the initial process of adaptation and internal discussions, the act of reaching for this foreign tool (cameras) became the catalyst for decolonising representational practices. A robust, disobedient, and proud attitude emerged, aimed at protecting threatened cultural identity and decolonisation of knowledge production practices. Ginsburg (1991) suggests cultural mediations occurring through film and video, which place indigenous media at the intersection of various discourses. She proposes that media productions allow indigenous communities to transform their cultural identity in a way appropriate to their needs:

when other forms are no longer effective, indigenous media offer a possible means social, cultural, and political — for reproducing and transforming cultural identity among people who have experienced massive political, geographic, and economic disruption. The capabilities of media to transcend boundaries of time, space and even language are being used effectively to mediate, literally, historically produced social ruptures and to help construct identities that link past and present in ways appropriate to contemporary conditions. (Ginsburg 1991, 92)

\section{Towards paradigm shift}

Let's bring it back to Sierra Nevada and analyse the transformation that took place over a decade of indigenous filmmaking in the region. As Mora (2015) points out, indigenous films are designed to transform lives in the villages. It is a collective work coming from the community and serving the community, and the methods of productions are very different from the Western professionals. Looking for own languages means being independent, autonomous, 
and decolonised. However, even if sometimes perceived as "boring," these films can and should educate the rest of society. Furthermore, indigenous cinema is not a separate genre (even though many film festivals present it as such), and it should be seen within categories of equality and inclusion.

The journey toward the current status quo (and recognition) for Zhigoneshi was long and challenging. Extensive external and internal negotiations preceded the filmmaking. This was followed by training, fundraising, and crew formation (focus on the collectiveness of the process). Mora underlines the initial difficulties due to a rather reserved (if not suspicious) attitude towards the technologies, especially by the elders. They often compared taking photos of the Sierra's landscape to showing 'naked pictures of a mother' because for the community Sierra is their mother (Mora 2015, 78). Only after a long-negotiated spiritual payment the filming work was approved. Another challenge was to fit lengthy monologues by the spiritual leaders within the film. Respecting extensive speeches by the elders while maintaining a reasonably well-paced edit which could be "digestible" for non-indigenous audiences required a skilful balancing act.

Other challenges to overcome concerned the way to position the body and look into the camera, or how to translate complex concepts and ideas into something that someone from outside of the community can understand and relate to - something I witnessed during my collaboration with the collective. But even with all that effort, the (external) understanding of the "message" can never be guaranteed. Following Stuart Hall's (1997) argument, intended messages are mostly negotiated and often rejected in the encoding-decoding communication process.

With that in mind, the trajectory from indigenous villages to international film festivals make Zhigoneshi's work not really impressive, but also highly influential. It proves that the films made by the collective achieved their goes: inform external allies and support and inform local communities.

At this point, it is necessary to take a huge shortcut from the challenging beginnings to the current place where Zhigoneshi (and, later, Yosokwi) filmmaking collectives are highly established in their activities. By necessity, this article will only focus on the selected elements of their legacy, namely, the significance of their work in the context of decolonisation of local knowledge.

In the interview conducted on 8 June 2014 by Valentina López Mape after "La Resistencia en Linea Negra" (one of the most engaged among Zhigoneshi films; for all titles, see the appendix) won the first award at the 1st Panorama of Colombian Cinema (5-11 June 2014, Paris), Villafaña said: "If we do not take the cameras and document what happens for ourselves, there will be people coming from outside and doing it for us. And despite their best intentions, their interpretations are not faithful to what we believe in" (López 2014). Therefore, he concluded, it becomes their responsibility to represent themselves in an audio-visual form since external many filming initiatives in the region consistently excluded the communities from the ownership of the process, effectively diminishing their role by reducing them to mere objects of representation. In the culture with strictly oral traditions and a strong hierarchy, where the film medium is relatively new, one will receive a very different story depending on who is behind the camera. As such, "external" films can never hope for the same depth as the ones made from within the community. Villafaña concluded unambiguously: "We cannot go on by ourselves. We need to be in alliance with the 'Younger Brother', but everyone needs to know their place" (ibid.).

In my numerous conversations with Amado Villafaña, he often mentioned that by speaking "for" the community, they are inevitably presented as unable to speak for themselves; a community from the past, either extinct or unable to adapt reality. This echoes MacDougall's conclusion that "by fixing its subjects irrevocably in the past, a film encroaches on their freedom and identity" (MacDougall 1998, 36). It is that suggestion of dependency and necessity to completely rely on the "external support" what bothers Villafaña the most. He has no doubt that the time has come to have this dialogue on equal terms, and he puts all the efforts to make it happen. 
$\mathrm{He}$ is aware that this might feel uncomfortable for the Western eyes, as it escapes an easy categorization. While Zhigoneshi represent a highly traditional society, they do not fit the description of exoticized "others" who have to rely on Western "experts" to make sense of who they are. In fact, they are actively subverting this hierarchy. This, as will be discussed further, represents a profound paradigm shift that offers a light of hope for decolonization of local knowledge.

At this point, it is essential to understand why certain representations (films) are made and what function they are designed to fulfil. This has been reinforced by Bill Nichols, famously unfavourable towards ethnographic films. He advocates blurring boundaries between politics and culture, between "here" and "there," while posing a fundamental question: "who has the responsibility and legitimacy (or power and authority) to represent others, not only in the sense of rendering likeness but also in the sense of 'speaking for' and 'presenting a case'?" (Nichols 1994, 63-64). Ironically labelling "us" as objective, professional and "disciplined," he suggests that we vex each other at the expense of others (ibid., 65). And perhaps most importantly, he ponders on the relevance of the created material to those filmed by asking "In what way does this representation matter to those it represents?" (Nichols 1994, 65). A similar attitude is expressed by Jay Ruby who advocates the transformation of the "disappearing Other" from a passive film subject and a "victim" of Western influence, into an engaged collaborator and author, suggesting that for a long time they remained mere transformations into "aesthetic creations, topics of scholarly interest, news items, and objects of pity and concern" (Ruby 2000, 199).

This fundamental shift in authority also relates to external expectations of what an "indigenous film" should be. Stereotypes and preconceptions drive the discourse on indigenous and non-indigenous aesthetics. Stephen Leuthold (1998) elaborates on that idea, contrasting indigenous and Western approaches to creative arts:

The very idea of "self-representation" as a personal and political concept challenges traditional notions of the self, where the self is thought of in terms of "subjectivity" or in the religious context of "soul". Western culture tends to separate the self into private and public dimensions, and this separation shows up in assumptions about art. (Leuthold 1998, 32)

It is also echoed by MacDougall $(2006,218)$, who suggests that indigenous media are a self-conscious expression of political and cultural identity, directed in part at countering representations by others. As a result of this intercultural flux and the increasing presence of indigenous productions in mass media, "their work is both a product of and commentary on contesting cultural identities" (ibid.).

Up till the time of my fieldwork in Colombia, nine films were signed by the Zhigoneshi Collective ${ }^{5}$, covering a decade of increasingly more and more accomplished filmmaking. The result and response might have surprised the makers - let's not forget that the initiative was initially a desperate response to violence and displacement with no further ambitions. As demonstrated, this initial aim was quickly replaced by another one, this time addressing more symbolic violence of cultural misinterpretation and colonisation of local knowledge. In that sense, the case of Amado Villafaña and his filmmaking collectives becomes a manifestation of MacLuhan's thesis: The very medium itself (indigenous film) became the message (they are more than capable to speak for themselves). This reversed hierarchy questioned the old status quo. The act of participation in the global exchange of intercultural communication became a political tool, a weapon, and a message in itself. The Arhuacos refused to be spoken about and spoken "for"; the only option is to speak "with" them. Effectively, their filmmaking became a form of political activism. 


\section{Decolonising local knowledge}

So how can filmmaking serve as an effective apparatus for self-identification, self-preservation, and decolonisation of local knowledge? More importantly, how can we measure this effectiveness? On a more profound level, we need to ask what happens with these films after they fulfilled their initial function. Can they be seen as yet another film genre which aims to entertain? What purpose do they serve for the local community, researchers, and international audiences over a decade since the beginning of the process? What is the meaning of this tremendous work that brought the Arhuaco story from villages of Sierra Nevada to international film festivals? And what are the consequences?

Finally, what is the legacy of the Arhuaco filmmaking? Can they inspire other forms of cultural resistance, another nonconformist battle to decolonise local knowledge? Do they (and the local circles analysing and disseminating their work) stand a chance to compete with overwhelmingly Western domination in the domain of knowledge production in a longer term? How can they continue their decolonisation process and the ongoing shift from Western (and Eurocentric) hegemony of knowledge, inviting a more inclusive and diverse consideration for local erudition and wisdom?

Luckily, there is an increasingly visible shift in European academic centres towards decolonising curriculums. With the West finally starting to understand the importance of inclusion and diversity in knowledge production (and distribution!), the Arhuacos provide a great example of a pioneering work where profound respect for tradition meets the understanding of the contemporary world of digital communication, fragmentarization and immediacy. What makes the Arhuaco case really successful is their wholistic approach, their uncompromised ability to focus on the bigger picture and not get distracted by the insignificant details. However, their work does not function in isolation from the plethora of audio-visual productions emerging all around the world on a daily basis. As such, their reliance on distribution is difficult to overestimate. The promise of successful participation in the international and intercultural dialogue relies on that. But distribution and access to modes of production (and reception) do not escape their own hierarchy and power relations. An intricate framework of infrastructure, training, regional and national priorities underline the complexity of the process. Of course, the list goes much longer. Also, to which point can they sustain their link to the community while increasingly adopting the role of intercultural spokespeople of their culture?

Zhigoneshi's rebellious opposition to the situation that placed them in an unfavourable light allowed them to take things into their own hands and decide how they wished to shape their participation in this local-global dialogue about (self)representation practices of indigenous communities. However, the price they had to pay was partial disconnection from a fully embraced traditional lifestyle (already disrupted by the initial violence).

In another place, I analyse how even inclusion of some indigenous titles in prominent film festivals (such as Berlinale) needs to be scrutinised before proclaiming success. With the emergence of the "Native" section in Berlinale since 2012, my hopes were very high. However, upon my visit to the festival, I quickly realised that the projections in the "Native" panel were scheduled in remote venues early morning or at the time which coincided with big festival premieres and other highly attractive screenings. As a result, I found myself in a small cinema, early in the morning, with a handful of other aficionados.

As already suggested, we could equally ponder whether labels such as "indigenous cinema" also contribute to this uneven distribution of power relations and, frequently, stigmatisation. Often, such categorisation provokes assumptions about the quality (and topics) of these productions, something Mora has analysed at length. Until we can overcome it, indigenous 
productions risk being undermined for the very fact that they are "indigenous productions." I agree with Mora, who suggests that the "indigenous" label stigmatises these films by placing them in a niche where they remain beyond the attention of big national distributors (who are mainly interested in commercial titles while the "indigenous" label does not usually promise commercial success). It is admirable to see the passion with which Mora fights to remove this stigma. With his wise guidance, there is a hope for, at least, a reconceptualization of this problematic category.

\section{Glocal dis-connection?}

How far have we developed the idea of the "global village" since McLuhan coined the term in the 1960s? What are global audiences over half a century later? And what is the link between local and global? How can they benefit each other? Of course, the idea of the internet and global communications connecting all the villages of the world proved to be somehow problematic. The combination of disproportionate distribution and coverage, curated suggestions often leaning towards propaganda, and unquestionable Eurocentrism (or Western-centrism) of knowledge doesn't allow communities like the Arhuacos truly equal participation in this intercultural circle of communication. Long-standing stereotypes about "indigenous" or "amateur" filmmaking further hinder the participation on equal rights. As a result, the undeniable success of the Zhigoneshi Collective still cannot be as impactful as it deserves to be.

I argue that, despite the apparent success, the term "glocal dis-connection" might be more adequate to describe indigenous communicators' current situation and their challenges. There is an undeniable link between local and global, but can we talk about socially meaningful connections and structures emerging from this situation? Fragmentarisation and non-linearity of digital culture (and, more specifically, the way it is consumed), poses a very grave risk of being taken out of the context, misinterpreted again, and used for wrong purposes. At the same time, the same technologies undeniably offer a unique opportunity to strengthen the impact and reach of Zhigoneshi's case.

In my previous analyses of the Zhigoneshi success, I talk about locality with global consequence. Here I would like to underline that our role, as non-indigenous researchers and collaborators, must go beyond simple acknowledgement of the importance of our local partners' knowledge. We need to facilitate their presence and visibility within the framework of our existing hubs of knowledge distribution (I am referring mostly to Europe and the United States) - academia, publishing, festivals, conferences, etc. Without that, we risk merely replicating the structure that many of us criticise in the first place. Our institutions (including grant-giving bodies) must acknowledge the importance and the necessity of this change and take visible long-term actions. Without that, we remain at the mercy of specialised events (i.e., indigenous film festivals and thematic conferences and events) which address specific audiences - those already interested in the subject. I am doubtful whether that can impactfully contribute to diversification and decolonisation of the discipline. Indeed, the expansion of who can create new media texts has been significant. However, we still must deal with (unconscious) bias which connects mainstream to mainstream-followers, favouring similarities, leading to uniformity.

Also, we need more examples like the ones of Zhigoneshi - wise content creators who understand their role in the process and are not focused on short-term goals or recognition but are taking their time to work tirelessly towards meaningful resolutions. 
Despite all the postcolonial wounds, dispossessions, and displacements, the Arhuacos do not want to be the victims but active agents who work for their recuperation, on the conditions they establish and govern. They are not asking for help; they ask to be listened to. They are competent to defend themselves, and they need allies, not saviours. The non-indigenous (and Western) world needs to respond by enabling relevant infrastructure and grounding for this knowledge exchange to occur. Of course, I use the Arhuaco case study as an example of a bigger problem that is not isolated to this specific community. We must appreciate the incredible effort and work they have done on their side. Breaking with long-standing traditions that placed them on the margin, and resuming their responsibility to speak for themselves using tools that were not part of their culture is not something that happens overnight. The enormous effort the community had to undertake to set this process in motion, convince the elders of the necessity of these actions, get the funding, and training, has already made a significant impact in various national and international circles. We just need to use this momentum to complete the decolonisation process.

\section{Challenges of representation}

Perhaps, however, we need to take a step backwards and ponder on the nature of representation (that is, filmmaking, in our example). Clifford Geertz attempts to understand what observation, experience, and storytelling really mean in his efforts to redefine the concept of culture and possible ways to describe it. He borrows the term "thick description" (which aims to describe behaviour and its context) from Gilbert Ryle and explains it as the object of ethnography. Its main characteristic is going beyond a mere report of what is happening ("thin description"), into a "stratified hierarchy of meaningful structures" (Geertz 2000, 7). He famously declared that "what we call our data are really our own constructions of other people's constructions of what they and their compatriots are up to" (Geertz 2000, 9).

We can identify three stages of interpretation taking place in a filmmaking process: the initial one during the real-life encounter with the subject; it is followed by the "translation" process (the actual filmmaking) and concluded by the reception processes of the final product. This complex process inevitably results in simplifications, reductions, or stereotyping. As if the process was not complicated enough, the fact that we are tackling indigenous representations adds to the complexity. Fatimah Tobing Rony describes how the viewer of an ethnographic film is usually confronted with "specimens of race and culture." This is, she suggests, how the "Other" or the "Savage" tends to be portrayed. It is never about an individual, but about the outsider's concept of the "otherness" (Rony 1996, 21-25). This curiosity influenced the relation between images and culture, as well as between images and power. Also, Catherine Russell (1999) warns us about the "reduction to sheer image and spectacle always [which] runs the risk of aestheticisation, of turning the Other into a consumable image" (62). This can result in a fetishist way of representing reality and the colonialist cinema of attractions, often applying exoticisation or eroticisation of the "Other." Russell suggests that ethnographic films replaced the "native villages" by its own performance: "early films took over these functions [of "human zoo', and 'part performance circus and part laboratory for physical anthropology'], eventually replacing imprisonment with visual objectification" (ibid., 52).

Rony shares that perplexity in the realisation of the commodification of the "Other" in film, describing how somebody's glance, or way of looking at another person, can mark that person the "Other." A movie screen pushes this feeling to yet another level, as in films, we find ourselves reflected in the eyes of "Others." Various forms of racial objectification in commercial cinema were consistently fixing the "Other" under the white audience's gaze (similarly to how female 
body was objectified by the gaze of a white, heterosexual male, as in the 1970s by Laura Mulvey). The subject's passivity confirms the power of the one who is watching on the screen and the fixations of gender and race power relations. These objectifying gazes are usually filtered through culturally inflicted stereotypes, for example, one of the "Primitive" or romanticised "Noble Savage." However, as Rony argues, even for someone who is watching samples of ethnographic work about an "unknown culture," it is never the "first time" as the "exotic is always already known" (1996, 6). This knowledge is based on cultural pre-assumptions and stereotypes, and this is precisely what the participants of this study aimed to contest with their work. This raises a question about the status of films made from the perspective of the "Other," where the identification (of the audiences) might occur on the border between the "Self" and the "Other."

But do indigenous self-representations in the eyes of external audiences manage to avoid the risk of distancing "otherness," regardless of who was behind the camera in the first place (and whose point of view we watch)? Definitions of "Otherness" are based on strict differentiation between the "norm" and the "difference," with strongly imposed power relations. Stereotyping is a vital tool to exercise the distinction of "Otherness," and it is essential for creating the boundaries of cultural meaning. Relating "Otherness" to the idea of the cultural stereotype, Nichols (1991) states that "The figure of the Other represents that which cannot be acknowledged or admitted within the culture that engenders it [...]. The Other embodies evil or chaos, excess greed or indolence, horror or monstrosity, the nefarious and the destructive" (204). Nichols suggests that mainstream cinema treats "Otherness" as a catalogue of one's "own disease, denial and anxiety" (ibid.). On the other hand, Steven Leuthold (1998) argues that "the image of the other is fixed [by stereotypes] so that it becomes more manageable" (26). Perhaps that is what has happened to the Arhuacos?

However, challenges of representation might be even more profound. The significance and impact of the first (visual) impression of the "Other" should not be ignored when discussing the idea of representing cultures. Writing about the Algerian revolution and the importance of immediately perceptible "visual differences" (here: clothing), Frantz Fanon (1965) notices that "it is by their apparel that types of society first become known, whether through written accounts and photographic records or motion pictures" (35). He reinforces his point by claiming that "the woman seen in her white veil unifies the perception that one has of Algerian feminine society" (Ibid, 36). This works similarly, I argue, for the external perception of indigenous peoples, often a long-haired, barefoot man, dressed in a simple hand-made tunic is likely to unify the perception of the whole indigenous community of a region. Such a simplified approach to the visual aspects of an indigenous person (and their culture, by extension) might potentially lead to distorted visions of "Otherness" for Western audiences. This spectacle of the "Other" relates to the fascination with "Otherness" and the implications of the representational practices of difference, regardless of whether it is a self-representation or an external view.

Following that, the danger of oversimplification that results in stereotyping is a common threat when interpreting cultures. Hall (1997) defines "stereotyping" as a process that "reduces people to few, simple, essential characteristics, which are represented as fixed by Nature." Stereotyping serves to fix the difference (and the boundaries) and exclude everything that does not belong, becoming "part of the maintenance of social and symbolic order" (ibid., 258). As already suggested, in case of indigenous communities, stereotyping is often designed to bring a soothing reassurance to Western audiences, comforting them that they are "in a better position" compared to the "uncivilised" individuals depicted on the screen. This is often undertaken without a basic understanding of the cultural differences and the very different systems of values, frequently resulting in a paternalistic attitude and reinforced power relations. Like "Otherness," stereotyping is centred around any form of difference: gender, race, ethnicity, sexuality, class, etc. Hall (1997) speaks about the symbolic cultural power, the "power to represent someone or something in a certain way." He compares stereotyping to a "symbolic violence" in this exercise of representational practices (ibid., 259). 
How can these patronising power relations be removed? Homi Bhabha (2004) postulated cultural hybridity, which potentially allows "difference without an assumed or imposed hierarchy" (5). Indigenous filmmaking seems to be aiming for this possibility. Bhabha also criticises the Eurocentric hegemony of knowledge, affirming that "there is a damaging and self-defeating assumption that theory is necessarily the elite language of the socially and culturally privileged" (ibid., 28).

Hall (1997) proposes that "other cultures" are given meaning by the discourses and practices of an exhibition in ethnographic museums of "the West"' (225). These exhibitions have their own poetics (discourses) and politics (relations of power). In more contemporary contexts, ethnographic films and other forms of exhibition often acquire a similar role. Even more importantly, this extends to hubs of contemporary knowledge production, which control and regulate current academic debates. The discourse surrounding these practices significantly contributes to how these "Other cultures" are being seen and given meaning. Therefore, the politics of representation cannot be seen as innocent (ibid., 223-225).

Regardless of all these challenges, I insist that, by looking at the Zhigoneshi filmmaking in a symbolic way as the McLuhanescue message, it still wins and achieves its goal.

\section{Dangers of Culture on Display}

Representing indigenous cultures also links to "visitability" of contemporary culture, as explored by Bella Dicks (2004). It refers to the effect of the distance we automatically produce by the very fact of placing the camera in front of our eyes. "Visitable representations" promise a condensed, attractive essence of the local life. Effectively, technology enables culture to be reproduced, but technology also distances us from the reality it aims to depict and converts in into simulations which rely on interpretation and are subject of stereotyping and simplification. The idea of culture on display implies that such display is designed to be a product that must be consumed.

What characterises the reception of culture on display is that, "whilst local groups are likely to want to recognise their own selves on display (with all the necessary complexity it entails), tourists [festival audiences?] may be expecting simply a reflection of received stereotypes about the other" (Dicks 2004, 30). The new "update" on the representation is unlikely to be produced regularly, and the existing one is rarely sufficiently negotiated and contested, which is highly problematic. Inevitably, forms of cultural display suffer from a degree of superficiality. It further perpetuates the divide between those who have access to the gaze of the "Other," and those (still in the majority), who can just afford to be gazed at (ibid. 40). This, effectively, comes down to determining who has the power to display cultures and, therefore, to regulate them.

McLuhanesque global village still remains in a very utopian stage, simply because of this unequal distribution of access to what it needs to become real. The exclusion from access to modern technologies means isolation and marginalisation. Moreover, the concept of "indigenous communities" should not be homogenised and understood as a unified concept. The situation of native communities worldwide is so diverse (and so is their access to technologies) that any generalisations in this subject are risky and ambiguous. Furthermore, as discussed, indigenous cinema is not a separate genre, and it should be seen within categories of equality and inclusion. The same should be said about definitions of ethnographic film. After all, can we not agree that most forms of representations try to depict cultures? 
Another aspect adding to the problem is the dichotomy embedded in the Zhigoneshi work, which links to the Western opposition of "modernisation" among indigenous cultures. There seems to be a fundamental misunderstanding and confusion about the difference between loyalty to their own culture and fight to survive and protect it (which often means reaching for foreign tools such as cameras!). Many external observers from the West often look for "authenticity" of indigenous cultures, which they feel might be lost at their developed places (Dicks 2004, 58). This is potentially very problematic coming from people who take advantage of the comforts of modern technologies but deny this right for the "Other" in the name of the beauty of the "primitive cultures." In some cases, such "living museums" are deprived of the right to progress and could only survive by being completely dependent on the flux of intrusive gaze of the visitors who "pay to watch." In such situations, the performed display of cultural identity becomes a commodity to sell, suggests Bella Dicks (Dicks 2004, 63).

Gilbert and Gleghorn (2014) echo the argument in "Recasting Commodity and Spectacle in the Indigenous Americas" that most indigenous self-representations are produced for primarily non-indigenous audiences, often becoming a commodity and spectacle. However, in analysing this exchange, it is essential to remember that "what is a commodity for one person might be a heritage to another" (6).

\section{Indigenous [in]visibility}

Given all the challenges and opportunities, what is the impact of Zhigoneshi's success (or failure) in decolonising the local knowledge? Leuthold $(1998,56)$ suggests Westerners' inability to comprehend the indigenous view of the world, often sacred and mystical and expressed in rituals. It seems to be incompatible with the Western materialistic and rationalistic thought. Such a situation often undermines indigenous expression as an appendage to "mainstream" (read Euro-American) developments on art (ibid., 58). Moreover, applying Western concepts to the description of indigenous forms of expression might be seen as a form of intellectual imperialism. This could result in harmful comparisons with the application of biased criteria. Following that, what seems to be essential is securing the place for the indigenous contributions to function on equal rights, next to any other knowledge producers.

In her far-reaching book, "Reclaiming Culture. Indigenous People and Self-Representation," Joy Hendry discusses questions of cultural exchange and personal identity. On many occasions, indigenous people actively engage in organising performances displaying their indigenous traits and values to the non-indigenous world. Hendry (2005) coins the term "cultural 'reclamation"' to describe "international links among and between indigenous peoples and outsiders interests in indigenous peoples" (179). She claims that the "reclamation of cultural forms by First Peoples who feel they were robbed of their identity and dignity is happening to a greater or lesser degree in all former colonies and some other configurations" (180). She poses the question of how these tendencies of people reviving their cultural diversity spread globally, despite predictions of convergence, suggesting that this might be part of the global communications trend. She argues that what fuels mutual interest is precisely the cultural difference, claiming that, if the indigenous people are willing to "share their cultural treasures with the outside world, in their way and at their investigation, it can be to the benefit of both parties" (2005, 180-196). I welcome this suggestion as the way forward to ensure a successful, equitable knowledge exchange.

Some scholars share my optimism about indigenous productions. In her "Native Recognition; Indigenous Cinema and the Western" (2012), Joanna Hearne claims a mutual influence of indigenous and non-indigenous cinema. She argues that the power of visual media helped the indigenous to take part in the intercultural discussion about their visibility. Others, like Michelle Raheja 
(2014), ask how indigenous films can impact the world and how they can harm or help the perception of the Native peoples. She poses the question whether the fact that indigenous films have been made since the silent era made any impact on improving their lives. However, we should not assume improving the lives of its subjects to be the effect of filmmaking, indigenous or not. In contrast, Gleghorn (2013) suggests the use of indigenous video as a tool for social justice, suggesting almost therapeutic qualities of the collective video-making practices among the communities.

\section{Conclusions, or resistance against hegemony of knowledge}

As demonstrated, the work of the Zhigoneshi collective represents many (often challenging) tensions in the attempt to protect local knowledge. Looking both outwards and inwards, their filmmaking processes address the inherent need to protect indigenous values and tradition. The work of the collective not only helped shed light on the situation in the Sierra, but it also provoked a broader discussion on politics of representation among indigenous communities. Underlying the difference between the indigenous and non-indigenous point of view, it also contributed to the ongoing debate on the importance of decolonisation local knowledge production and dissemination. But perhaps most importantly, by regaining agency and responding to all the forms of violence against their culture, the community confirmed their internal strength, perseverance and resistance which helped them not only survive but shine with an example. The process needs to continue, and I am optimistic about potential outcomes.

Zhigoneshi actively disobeyed the laws of "coloniality," which follow cultural hierarchies that enable the maintenance of domination relations. I would like to reinforce the fact that knowledge is power, knowledge (often) is a representation, and knowledge depends on distribution. We could (and should) learn a lot from local knowledge of communities like the Arhuacos as they demonstrate the hope that local and global can be in symbiosis when they serve the common goal of communication and connections and ignore divisive subordination.

I'll conclude with Villanueva' postulate (Mora 2015), which proposes communication (as a field and practice) as a central point for de-coloniality, understood as de-westernisation and steps towards post-westernisation (Westernization understood as "political or discursive action by which Western countries control historically - by elimination, absorption or marginalisation - to the non-Western world") $(2020,270)$. Communities of Sierra Nevada de Santa Marta developed their strong and coherent voice. What the rest of us need to do is to tune in and allow this voice to be heard. 


\section{[NOTAS]}

1. In my translation: The Arhuacos carry defects which are common to almost all the Indians, which are generally selfish, suspicious, without aspirations, inclined to laziness and drunkenness.

2. In my translation: The abuse of cocaine produces in the Arhuacos a series of rare physiological and moral phenomena [...] It makes them appear timid or cowardly; it makes them taciturn and mysterious; they remain almost continuously in a semi-lethargic state.

3. They changed the way we dress, against the order of our indigenous authorities who insisted to let us keep our long hair and traditional clothing (my translation).

4. In my translation: The missionaries were always opposing that we continue our traditions; they wanted us to follow the rules of the civilization.

5. 1. "Yuawika sia: En el río del entendimiento", (Yuawika sia: On the River of Understanding), 2007; "Yetsikin: Guardianes del agua", (Yetsikin: The Water Guardians), 2007; "Palabras Mayores I" (Words of Wisdom I), 2009; "Palabras Mayores II" (Words of Wisdom II), 2009; "Yosokowi" (Yosokowi), 2010; "Nabusímake: Memorias de una independiencia", (Nabusímake: Memories of Independence), 2010; "Resistencia en la Línea Negra" (Resistance on the Dark Line), 2011; "Sey Arimaku: La otra oscuridad" (Sey Arimaku: The Other Darkness); Mora, Pablo - dir, 2012; "Naboba, visión ancestral del agua del pueblo Arhuaco" (Naboba, Ancestral vision of the water of the Arhuaco peoples), 2014. 
[REFERENCES]

Bhabha, Homi. 2004. The Location of Culture. London and New York: Routledge

Bhambra, Gurminder K. 2014. "Postcolonial and decolonial dialogues". Postcolonial Studies, 17:2, 115-121, DOl: 10.1080/13688790.2014.966414

Dicks, Bella. 2004. Culture on Display: The Production of Contemporary Visitability. (Issues in Cultural and Media Studies), London: Open University Press

Ereira, Alan. 2009. The Elder Brother's Warning.

Ereira, Alan. 1992. The Heart of the World.

Fanon, Franz. 1965. A Dying Colonialism. New York: Grove Press.

Geertz, Clifford. 2000. The Interpretation of Cultures. New York: Basic Books.

Gilbert, Helen and Gleghorn, Charlotte. 2014. Eds. Recasting Commodity and Spectacle in the Indigenous Americas. London: Institute of Latin American Studies, School of Advanced Study, University of London.

Ginsburg, Faye. 1991. "Indigenous Media: Faustian Contract or Global Village." Cultural Anthropology, Vol. 6, No.1, pp92-112, Wiley.

Gleghorn, Charlotte. 2013. "Reconciliation en minga: Indigenous Video and Social Justice in Colombia." Journal of Latin American Cultural Studies. 22:2, 169-194.

Hall, Stuart. Ed. 1997. Representation: Cultural representations and signifying practices. London: Sage Publications.

Hearne, Joanna. 2012. Native Recognition. Indigenous Cinema and the Western. New York: Suny Press, State University of New York Press.

Hendry, Joy. 2005. Reclaiming Culture. Indigenous People and SelfRepresentation. New York: Pelgrave Macmillan.

Leuthold, Stephen. 1998. Indigenous Aesthetics, Native Art, Media and Identity. Austin: University of Texas Press.

López Mape, Valentina. 2014. "VOSTF Entrevista a Amado Villafaña, codirector del documental Resistencia en la línea negra". October 12, 2014. Interview, 14:50. https://www.youtube.com/ watch?v=rEoY5AcN460

Lulkowska, Agata. 2018. "Voice of the Arhuacos: Transcending the Borders of "Indigenous" Filmmaking in Colombia." The Journal of Communication and Media Studies. Common Ground Research Network. 4(2).

Lulkowska, Agata. 2020. "The Voice of the Sierra Nevada: Intercultural Communication and De-colonial Strategies in the Arhuaco Filmmaking and Collaborations." Anthrovision Vaneasa Online Journal. Vol. 7.2.

MacDougall, David. 2006. The Corporeal Image: Film, Ethnography and the Senses. Princeton and Oxford: Princeton University Press.

MacDougall, David. 1998. Transcultural Cinema. Princeton University Press.

McLuhan, Marshall. 1964. Understanding Media. Routledge.

Mora, Pablo. Ed. 2015. Poéticas de la Resistencia. El Video Indígena en Colombia. Bogotá: Cinemateca Distrital.
Nichols, Bill. 1991. Representing Reality: Issues and Concepts in Documentary. Blooming and Indianapolis: Indiana University Press.

Nichols, Bill. 1994. Blurred Boundaries: Questions of Meaning in Contemporary Culture. Bloomington and Indianapolis: Indiana University Press.

Raheja, Michelle H. 2014. "Will making movies do the sheep any good?' The afterlife of Native American images.|" Recasting commodity and spectacle in the indigenous Americas. London: School of Advanced Study: University of London.

Rony Tobing, Fatimah. 1996. The Third Eye: Race, Cinema and Ethnographic Spectacle. Durham and London: Duke University Press

Ruby, Jay. 2000. Picturing Culture. Explorations of Film and Anthropology. Chicago and London: The University of Chicago Press.

Russell, Catherine. 1999. Experimental Ethnography: The Work of Film in the Age of Video. Durham and London: Duke University Press.

Schiwy, Freya. 2009. Indianizing Film. Decolonization, The Andes, and the Question of Technology. New Brunswick, New Jersey, and London: Rutgers University Press.

Torres Márquez, Vicencio. 1978. Los Indios Ahuacos y "La Vida de la Civilisation."Bogotá: Libreria y Editorial America Latina.

de Vinalesa, Padre Jose. 1952. Indios Arhuacos de la Sierra Nevada de Santa Marta; Descripción geográfica - Costumbres de los Indios, Idioma Arhuaco. Bogotá: Editorial Iqueima. 


\section{[FILMS]}

Ereira, Alan, dir. 2012. Aluna. Colombia: Sunstone Films.

Ereira, Alan, dir. 1990. The Heart of the World: Elder Brother's Warning. British Broadcasting Corporation.

Gardner, Roberht, dir. 1988. Ika Hands. Watertown, MA: Documentary Educational Resources.

Mora, Pablo, dir. 2012. Sey Arimaku: La otra oscuridad. Zhigoneshi Collective.

Vidal Antonio Rozo. 1964. El Valle de los Arhuacos. Calima, Colombia: Empresa Cinematográfica Colombiana Calima.

Villafaña, Amado, dir. 2014. Naboba, visión ancestral del agua del pueblo Arhuaco. Zhigoneshi Collective.

Zhigoneshi Collective. 2007. Yuawika sia: En el río del entendimiento.

Zhigoneshi Collective. 2007. Yetsikin: Guardianes del agua.

Zhigoneshi Collective. 2009. Palabras Mayores I.

Zhigoneshi Collective. 2009. Palabras Mayores II.

Zhigoneshi Collective. 2010. Yosokowi.

Zhigoneshi Collective. 2010. Nabusímake: Memorias de una independencia.

Zhigoneshi Collective. 2011. Resistencia en la Línea Negra. 